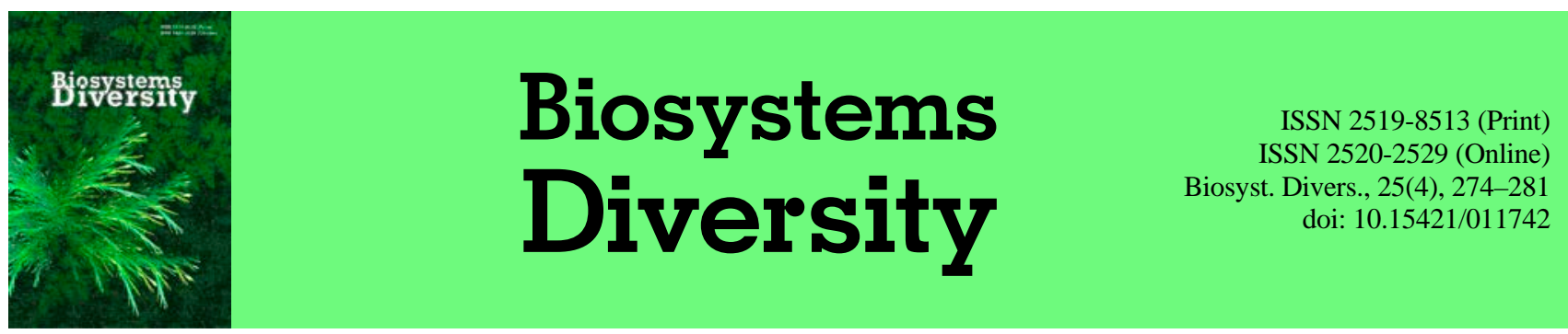

\title{
Ecological-anatomical characteristics of some Tragopogon (Asteraceae) species of the flora of Ukraine
}

\author{
O. A. Futorna****, V. A. Badanina***, S. L. Zhygalova** \\ *O. V. Fomin Botanical Garden, National Taras Shevchenko University of Kyiv, Kyiv, Ukraine \\ **N. G. Kholodny Institute of Botany of National Academy of Sciences of Ukraine, Kiev, Ukraine \\ ***Taras Shevchenko National University of Kyiv, Kyiv, Ukraine
}

\section{Article info}

Received 17.10.2017

Received in revised form 14.11.2017

Accepted 16.11.2017

O. V. Fomin Botanical Garden, National Taras Shevchenko University of Kyiv,

Symon Petlyura st., 1 , Kyiv, 01601, Ukraine. E-mail:

oksana_drofa@yahoo.com

N. G. Kholodny Institute

of Botany of National Academy of Sciences of Ukraine,

Tereschenkivska st., 2, Kyiv, 01004, Ukraine.

E-mail:

zhygalova2015@gmail.com

Taras Shevchenko National University of Kyiv, Akademik Glushkov ave., 2 ,

Kyiv, 03022, Ukraine.

E-mail: florist_27@ukr.net
Futorna, O. A., Badanina, V. A., \& Zhygalova, S. L. (2017). Ecological-anatomical characteristics of some Tragopogon (Asteraceae) species of the flora of Ukraine. Biosystems Diversity, 25(4), 274-281. doi:10.15421/011742

The results of the study of the anatomical structure of assimilating organs of the three species of the genus Tragopogon are described. Nowadays the anatomical structure of vegetative organs of representatives of many taxa have already been researched. The in-depth study of the anatomical structure of species of the genus Tragopogon which was conducted revealed the presence of different ways of structural adaptation of plants to growing on sands, on the one hand, and, on the other hand, revealed that the investigated taxa have structurally different leaves and stems, whose main features do not depend on the influence of conditions of existence. Almost all species of the genus Tragopogon are mesoxerophytes, the purpose of this work was to investigate the species of the Tragopogon genus which inhabit sandy soil. Such researches will be useful for solving problems of genus taxonomy and for detection of adaptive features of plants. The specimens for investigation were collected from a natural habitat. The plants were in the generative phase of development. Leaves and stems in the middle of their length were conserved for investigation. As a result, we detected features which distinguish species but they can not be used for taxonomy, as they depend on ecology. Thus, the studied species differ in the length of leaf lamina. T. ucrainicus has the thinnest lamina and T. orientalis has the thickest one. In addition, $T$. orientalis has the most laminaled mesophyll (it is distinctly multilayered). The type of mesophyll varied from isolateral (T. borysthenicus and T. ucrainicus) to pseudo-isolateral (T. orientalis). The numbers of layers of palisade parenchyma (both adaxial as well as abaxial) hardly varied at all between species, except that a third layer of cells was rarely represented in $T$. orientalis. The species differ in the degree of development of spongy parenchyma. It is most developed in $T$. orientalis (five or six layers of cells) and it is less developed in $T$. borysthenicus (two layers of cells). There are differences between the species in the anatomical structure of the stem. Thus, T. borysthenicus has the most developed chlorenchyma (four or five layers) and in T. orientalis it is less developed (two or three layers of cells). Cholophylless parenchyma is represented by the greatest number of layers in $T$. borysthenicus and by a smaller number of layers in $T$. ucrainicus, it is less developed in T. orientalis. The conduction system of the three investigated species is developed approximately equally. As the result of the analysis, it is possible to conclude that in the anatomical structure of all investigated species of the genus Tragopogon there is a combination of xeromorphic and mesomorphic features . T. borysthenicus from the Black Sea Biosphere Reserve exhibits the most xeromorphic features. The least xeromorphic characteristics are shown by T. orientalis from the sandy terraces of the Desna river (Chernihiv Region). We singled out a complex of anatomical features which can be additional diagnostic ones for the investigated species. T. borysthenicus is characterised by the presence of cortical conducting vascular bundles and by the placement of laticifers in the perimedullar region of the pith; in T. ucrainicus laticifers are also in the perimedullar region but cortical vascular bundles are absent; cortical vascular bundles are observed in $T$. orientalis but laticifers are placed all over the pith.

\section{Еколого-анатомічна характеристика деяких видів роду Tragopogon (Asteraceae) флори України}

\author{
О. А. Футорна ****, В. А. Баданина***, С. Л. Жигалова**
}

\author{
*Ботанічний сад імені акад. О. В. Фоміна, Київський національний університет імені Тараса Шевченка, Київ, Україна \\ **Інститут ботаніки імені М. Г. Холодного НАН України, Київ, Украӥна \\ ***Київський національний університет імені Тараса Шевченка, Київ, Украӥна
}

Досліджено анатомічну структуру видів роду Tragopogon флори України. Встановлено, що анатомічна будова асимілювальних органів псамофітних видів роду Tragopogon характеризується комплексом ксероморфних і мезоморфних ознак. Спільні ксероморфні ознаки для досліджених видів - це амфістоматичний тип листка, потужний шар кутикули у поєднанні 3 товстостінними епідермальними клітинами, 
наявність безхлорофільної паренхіми та включень. Ознаки мезоморфності - не занурені продихи, слабкий розвиток провідної системи та механічних елементів, крупноклітинність тканин стебла та листка. Для кожного з досліджених видів комплекс таких ознак - адаптивний, він виник у ході індивідуального розвитку рослин за впливу певних умов навколишнього середовища. Чим менш аридними стають умови, тим більш мезоморфною виявляється структура листка та стебла видів роду Tragopogon. Ступінь мезоморфності, за нашими даними, збільшується в напрямку з півдня на північ. Найбільш ксероморфною структурою характеризується T. borysthenicus iз Чорноморського заповідника, та найменшою - T. orienthalis із піщаних терас р. Десна (Чернігівська обл.). Виділено комплекс анатомічних ознак, які відрізняють види та можуть слугувати як додаткові діагностичні: T. borysthenicus характеризується наявністю корових провідних пучків і розміщенням молочників у перимедулярній зоні серцевини; у T. исrainicus молочники також містяться в перимедулярній зоні, але корові пучки відсутні; у T. orienthalis спостерігаються корові провідні пучки, але молочники містяться по всій серцевині.

Ключові слова: таксономія; псамофіти; анатомія рослин; корові провідні пучки; адаптація; Asterales

\section{Вступ}

Нині вже досліджено анатомічну будову вегетативних органів представників багатьох таксонів, що відображено в монографічних зведеннях (Solereder, 1899; Stocker, 1928; Metcalfe and Chalk, 1950) і численних публікаціях у періодичних виданнях (Butnik and Saidov, 1971; Caroliin et al., 1978; Butnik and Tymchenko, 1987). Інформація про анатомічну структуру тих чи інших видів увесь час збільшується. Анатомічні ознаки найчастіше використовують для вирішення тих або інших питань систематики рослин, а також для з'ясування екологічної пластичності видів (мінливі чи залежні від умов навколишнього середовища) (Shijrevdamba, 1989; Shijrevdamba and Gamalej, 1990; Grigore and Toma, 2010). У систематиці рослин анатомічні ознаки застосовуються, головним чином, на трьох таксономічних рівнях - родинному, родовому чи видовому (Metcalfe and Chalk, 1950). У різних таксономічних групах групи видів із заплутаною систематикою та думки авторів щодо значущості таксономічних ознак часто не збігаються, що викликає різні трактування та розбіжності у «Флорах...» і «Визначниках...». До таких груп належить рід Tragopogon L. (Asteraceae), який об'єднує 100-150 видів (Borisova, 1964; Tsvelev, 1989) одно-, дво-, багаторічних трав'янистих рослин. Ареал роду охоплює більшу частину Європи, регіони Азії з помірним кліматом $\mathrm{i}$ північно-західні райони Африки. Для території України наводять від 3 (Shmal'gauzen, 1897) до 17 (Klokov, 1965) видів роду, які належать до однієї секції Brevirostres Kuth.

Практично всі види роду Tragopogon - мезоксерофіти, лише деякі псамофіти, бо окремі види легко «переходять» на засолені грунти. У цій статті ми мали на меті дослідити види роду Tragopogon, приурочені до піщаних грунтів. Такі дослідження будуть корисними як для вирішення проблем систематики роду, так і для виявлення адаптивних ознак рослин. Bykov and Stepanova (1953) вважали, що методично правильно поставлені дослідження дозволяють за анатомічною будовою правильно оцінювати ступінь адаптації рослин до певних умов існування, а також робити висновки про історію розселення видів, про екологію їх предків. Адаптація - один із найважливіших механізмів, який підвищує стійкість біологічної системи, в тому числі рослинного організму, до умов існування. Чим організм більше адаптований до якогось фактора, тим він стійкіший до його коливань. Більшість модифікацій, які виникають у межах норми реакції, мають адаптивне значення, вони відповідають змінам навколишнього середовища та забезпечують виживання рослин в екстремальних умовах навколишнього середовища. Піщані грунти позбавлені зв'язності, пухкі, безструктурні. Розвиток рослин на них обмежується низкою факторів, головні з них - недостатня кількість вологи, високі літні температури, бідність пісків на гумінові речовини тощо.

Нині відсутні детальні морфологічні та анатомічні дослідження представників даного роду. Відомості стосовно анатомічної структури тих або інших видів фрагментарні. Öznur Ergen Akçin (2007), досліджуючи анатомічну структуру їстівних та лікарських рослин Західної та Центральної частини Причорноморського регіону Туреччини, вивчав морфолого-анатомічну структуру T. latifolius Boiss. Qureshi et al. (2008) вперше дослідили морфологічну будову епідерми листкової пластинки та пилкові зерна двох видів роду Tragopogon флори Пакистану: T. dubius та T. gracilis.
Ця стаття - перша спроба дослідити анатомічну структуру видів роду Tragopogon флори України.

\section{Матеріал і методи досліджень}

Для дослідження відібрано листки та стебла (у середній частині їх довжини) рослин із природних місць зростання в генеративній фазі розвитку. Зразки T. borysthenicus зафіксовані в Херсонській обл., Голопристанський район, Чорноморський Державний біосферний заповідник, Івано-Рибальчанська ділянка, піщані тераси р. Дніпра, T. ucrainicus - у м. Київ, лівий берег р. Дніпро, T. orienthalis - у Чернігівській обл., окол. с. Красне; піщані тераси заплави р. Десна.

Для фіксації рослинного матеріалу використовували ФОС (формалін - оцтова кислота - спирт). Беручи до уваги зміни будови мезофілу та проекції епідермальних клітин у різних частинах рослини, для аналізу завжди брали фрагменти стебла та листка в середніх частинах їх довжини. Мікропрепарати листків і стебел виготовляли за загальноприйнятими методиками (Furst, 1979). Епідермальну тканину вивчали додатково, розглядаючи іï з поверхні листка, для чого готували парадермальні препарати (середню третину листка досліджуваних видів витримували в мацерувальному розчині) (Furst, 1979). Описи анатомічної будови та виміри клітин проводили, використовуючи мікроскоп LM Carl Zeiss (PrimStar) 3 камерою ScopeTek (Etrek DCM 510). Лінійні розміри мікрооб'єктів визначали 3 використанням програми Axiovision 4.8. Для розрахунку статистичних показників ознак об’єм вибірок складав 50 вимірів для кожної. Під час підрахунку кількості клітин на одиницю площі об'єм вибірок складав 10 вимірів (Vasiljev, 1988). Опис анатомічних ознак листків і стебел здійснювали за методикою Vasil'ev (1988) та Zaharevich (1954). Препарати забарвлювали сафраніном, гематоксиліном і суданом III (Furst, 1979). Математична обробка даних здійснена програмою Statistica 10.0.

\section{Результати}

Проаналізуємо анатомічні характеристики асимілювальних органів видів роду Tragopogon.

T. borysthenicus Artemcz. Листок. На поперечному зрізі листкова пластинка V-подібної форми. Товщина листкової пластинки дорівнює 275,1 \pm 5,9 мкм, (табл. 1) і листок характеризується як товстий. Шар кутикули спостерігається на обох епідермах (рис. 4). У парадермальній площині клітин епідерми їх обриси та проекції варіюють за формою. В районі середньої жилки та великих бічних провідних пучків вони мають прямі обриси та прямокутні проекції, на відміну від інших епідермальних клітин, в яких обриси прямолінійно-округлі, а проекції - розпластані (рис. 5a). Листок амфістоматичний, тобто продихи спостерігаються на обох епідермах. Продихи оточені трьома або чотирма клітинами, які не відрізняються від інших клітин епідерми, тобто вони аномоцитного типу. Продихи неорієнтовані, розміщені більш або менш рівномірно по всій поверхні листкової пластинки, на одному рівні з основними епідермальними клітинами.

На поперечному зрізі клітини обох епідерм мають прямокутну форму та потовщені зовнішні стінки (ті, що межують із мезофілом). Ці стінки в 3,0-3,5 раза товщі, ніж бічні клітинні стінки. Формою, розмірами, обрисами та проекціями клітини 
обох епідерм подібні між собою. Епідермальна тканина одношарова, загальна їі товщина дорівнює $20,1 \pm 1,2$ мкм, що становить 7,0\% від товщини листка. Товщина верхньої епідерми дорівнює 10,1 \pm 0,8 мкм, товщина нижньої 10,0 $\pm 0,4$ мкм.

Мезофіл ізолатеральний, тобто палісадна паренхіма наявна 3 обох боків листка. Його товщина дорівнює $227,7 \pm 3,1$ мкм. Складений він сімома шарами клітин, характеризується як багатошаровий товстий. Адаксіальна та абаксіальна палісадні па- ренхіми представлені двома шарами клітин. Клітини субепідермального шару верхньої та нижньої палісадних тканин мають однакову витягнуто-циліндричну форму та розміщені щільніше, порівняно з іншим шаром, клітини якого округлішої форми та пухкіше розміщені. Між палісадною паренхімою містяться три шари клітин губчастої тканини. Клітини її овальної форми, з великою кількістю міжклітинників. Спостерігається чіткий перехід від палісадної тканини до губчастої.

Таблиця 1

Анатомічні ознаки листка видів роду Tragopogon $(\mathrm{n}=250)$

\begin{tabular}{|c|c|c|c|c|c|c|}
\hline Ознаки & Середнє, мкм & $\begin{array}{c}\text { Стандартна } \\
\text { похибка, мкм }\end{array}$ & Мінімум, мкм & Максимум, мкм & $\begin{array}{l}\text { Стандартне } \\
\text { відхилення }\end{array}$ & $\begin{array}{l}\text { Коефіцієнт } \\
\text { варіації, \% }\end{array}$ \\
\hline \multicolumn{7}{|c|}{ T. borysthenicus } \\
\hline Товщина листкової пластинки & 275,1 & 5,87 & 248,4 & 298,0 & 18,56 & 6,0 \\
\hline Товщина мезофілу & 227,7 & 3,13 & 211,7 & 245,4 & 9,91 & 4,0 \\
\hline Товщина верхньої епідерми & 10,1 & 0,76 & 6,3 & 15,1 & 2,43 & 24,0 \\
\hline Товщина нижньої епідерми & 10,0 & 0,41 & 8,2 & 12,0 & 1,30 & 13,0 \\
\hline \multicolumn{7}{|c|}{ T. ucrainicus } \\
\hline Товщина листкової пластинки & 218,3 & 5,17 & 188,6 & 242,5 & 16,36 & 7,0 \\
\hline Товщина мезофілу & 172,7 & 6,00 & 144,1 & 193,7 & 18,97 & 11,0 \\
\hline Товщина верхньої епідерми & 8,4 & 0,33 & 7,0 & 10,3 & 1,05 & 12,0 \\
\hline Товщина нижньої епідерми & 8,4 & 0,33 & 7,2 & 10,5 & 1,06 & 13,0 \\
\hline \multicolumn{7}{|c|}{ T. orienthalis } \\
\hline Товщина листкової пластинки & 291,8 & 4,11 & 274,1 & 314,3 & 13,00 & 4,0 \\
\hline Товщина мезофілу & 253,1 & 5,33 & 229,2 & 276,7 & 16,87 & 6,0 \\
\hline Товщина верхньої епідерми & 8,2 & 0,49 & 5,7 & 11,3 & 1,54 & 18,0 \\
\hline Товщина нижньої епідерми & 7,4 & 0,40 & 5,3 & 9,6 & 1,26 & 17,0 \\
\hline
\end{tabular}

Провідна система слабко розвинена, представлена центральним провідним пучком і бічними пучками, які варіюють за розміром. У центральному провідному пучку нараховується 12-14 середнього розміру судин ксилеми. Безхлорофільна паренхіма добре розвинена, більше іiі з адаксіального боку листка. Вона оточує провідні елементи пучка, складена великими тонкостінними клітинами, які межують 3 абаксіального боку 3 коленхімою та сусідніми провідними пучками.

Коленхіма добре розвинена, іiі потужний тяж спостерігається $з$ абаксіального боку листка під флоемою центрального провідного пучка. Міститься вона субепідермально та тягнеться в обидва боки від центрального пучка до сусідніх бічних провідних пучків. Крім того, ії тяжі спостерігаються по краях листка, межуючи з епідермою та мезофілом.

Бічних провідних пучків нараховується 9-10 пар, з яких дві пари великих (лише в 1,5 раза менші центрального), а решта дуже дрібні. Провідні пучки більшого розміру мають обкладки з безхлорофільної паренхіми, оточені коленхімою, яка межує 3 обома епідермами, утворюючи таким чином коленхімні тяжі, що з'єднують протилежні боки листка. У менших за розміром пучках чітко наявні обкладки з безхлорофільної паренхіми та відсутня механічна тканина.

Включення спостерігаються у мезофілі, епідермі та безхлорофільній паренхімі.

Стебло. На поперечному зрізі форма стебла практично округла. Клітини епідерми дрібні, з потовщеними зовнішніми та їм протилежними стінками (рис. 1). Епідермальна тканина однорядна, але інколи зустрічаються місця, де спостерігається ще один внутрішній шар клітин епідерми. На поперечному зрізі стебла чітко виділяються корова паренхіма, провідна система та серцевина.

До складу корової паренхіми входять хлоренхіма, безхлорофільна паренхіма, луб'яні волокна, крім цього спостерігаються повноцінні корові провідні пучки. Хлоренхіма розміщується субепідермально. Представлена вона чотирма - п’ятьма шарами щільно розміщених, овальної форми клітин. Час від часу хлорофілоносну паренхіму переривають луб'яні волокна, які з одного боку межують з епідермою, а з іншого - 3 безхлорофільною паренхімою. Остання представлена шістьма - вісьмома шарами клітин. Клітини ії великі, мають тонкі стінки. У безхлорофільній паренхімі зустрічаються невеликі корові провідні пучки, які мають і флоему, і ксилему.
Провідна система пучкового типу. Пучки середнього розміру. Флоема розміщується невеликими «шапками» над ксилемою. Між пучками флоеми міститься два - три ряди клітин безхлорофільної паренхіми. У найбільших пучках нараховується 14-15 великих судин ксилеми, які розміщені переважно у три ряди по чотири - п'ять судин у кожному. Міжпучкові зони дуже широкі, складені п'ятьма - шістьма рядами клітин.

Серцевина добре розвинена, на поперечному розрізі стебла займає приблизно половину його площі. Ї̈і клітини тонкостінні та дещо варіюють за розміром. Перимедулярна зона виражена не чітко, заходить глибоко між провідними пучками. Досить велика кількість молочників міститься в цій частині стебла, особливо у перимедулярній зоні. Крім цього включення містяться у клітинах безхлорофільної паренхіми, які розташовані над флоемою.

T. ucrainicus Artemcz. Листок. На поперечному зрізі форма листкової пластинки, як і в попереднього виду, V-подібна, із загнутими вгору краями. Листкова пластинка завтовшки 291,8 \pm 4,1 мкм, тобто має середню товщину. Ледь помітний шар кутикули спостерігається на обох епідермах.

У парадермальній площині клітини обох епідерм, як і у козельців дніпровських, варіюють за формою проекцій та обрисів. У районі середньої жилки та найбільших бічних провідних пучків клітини епідерми мають прямі обриси та прямокутні проекції. Інші епідермальні клітини мають розпластані проекції та звивисті обриси. Як і у попереднього виду, продихи аномоцитного типу спостерігаються на обох епідермах. Розміщені вони більш-менш рівномірно та, на відміну від попереднього виду, дещо нижче рівня основних епідермальних клітин.

Епідермальна тканина одношарова. Її товщина становить $16,8 \pm 0,7$ мкм, або 7\% товщини листка. Клітини обох епідерм на поперечному зрізі дещо витягнені в горизонтальному напрямку, в районі середньої жилки трішки меншого розміру. Як і у попереднього виду, зовнішні та їм протилежні клітинні стінки потовщені. За розміром клітини обох епідермальних тканин практично однакові. Товщина верхньої та нижньої епідерм відповідно дорівнює 8,4 $\pm 0,3$ та 8,4 \pm 0,3 мкм (табл. 1).

Мезофіл, як і у попереднього виду, ізолатеральний, його товщина дорівнює $172,7 \pm 6,0$ мкм; представлений шістьма (рідко сімома) шарами клітин і характеризується як помірношаровий. Палісадна тканина складається із двох шарів клітин адаксіальної палісадної паренхіми та такої ж кількості шарів клітин абаксіальної паренхіми. Формою та розміром клітини 
верхньої та нижньої палісадних паренхім не відрізняються, але слід зазначити, що клітини адаксіальної палісадної паренхіми розміщені пухкіше, ніж клітини адаксіальної паренхіми. Губчаста тканина складена двома - трьома шарами округлих та щільно розміщених клітин, які містяться, головним чином, у проміжках між провідними пучками.

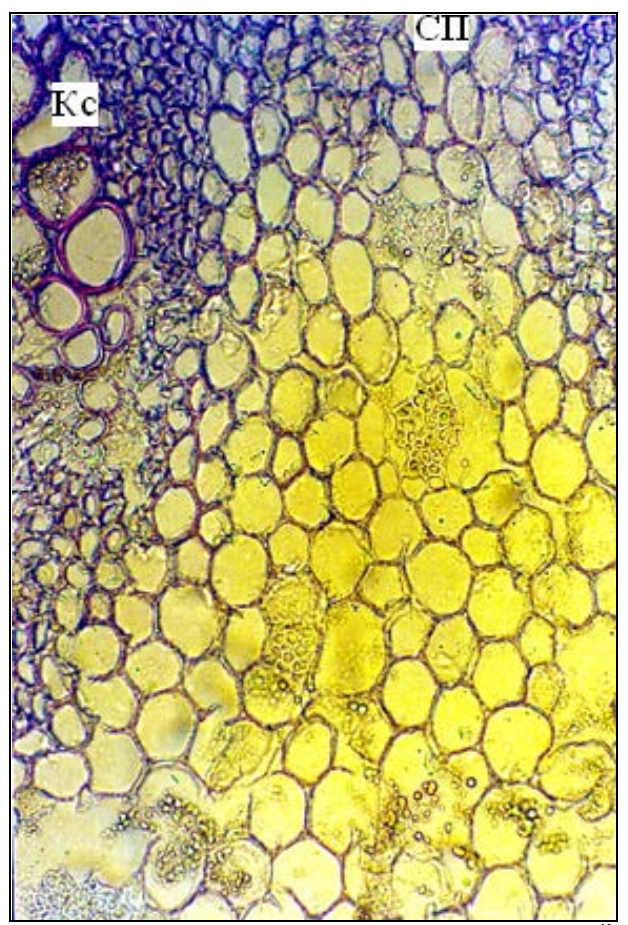

Рис. 1. Анатомічна будова стебла T. borysthenicus ( $\left.{ }^{\mathrm{x}} 400\right)$ : СП - серцевинні (медулярні) промені, Кс - ксилема

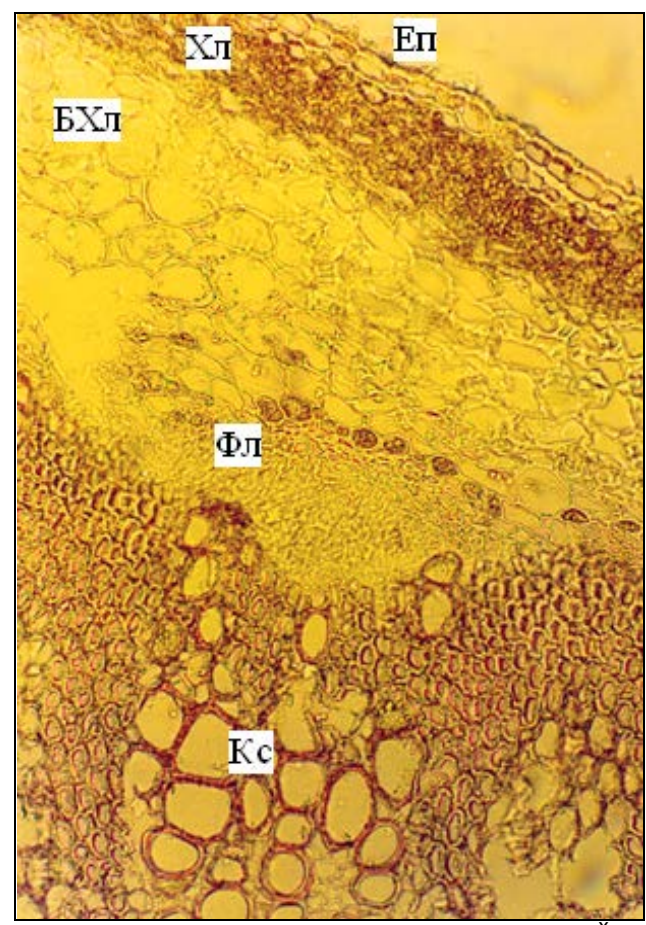

Рис. 2. Анатомічна будова стебла T. orienthalis $\left({ }^{\mathrm{x}} 100\right)$ : Кс - ксилема, Фл - флоема, БХл - безхлорофільна паренхіма, Хл - хлоренхіма, Еп - епідерма

Провідна система слабко розвинена, представлена невеликим центральним провідним пучком і бічними провідними пучками, які варіюють за розміром: від великих (які лише трохи поступаються у розмірі центральному) до зовсім дрібних. Центральний провідний пучок зверху та знизу межує з безхло- рофільною паренхімою, а з боків - із мезофілом. У цього виду безхлорофільна паренхіма значно менше розвинена, ніж у попереднього. 3 обох боків листка між епідермою та водоносною тканиною спостерігаються тяжі з клітин коленхіми. Ксилема менш розвинена, ніж у попереднього виду. У центральному провідному пучку нараховується шість невеликих судин (але значно більших, ніж у попереднього виду), які розміщені у два три ряди по дві - три судини в кожному. Флоема, навпаки, у цього виду займає приблизно удвічі більшу площу, ніж у попереднього. На поперечному зрізі спостерігаються дві пари великих бічних провідних пучків та 12-13 дуже дрібних. Усі вони мають чітко виражені обкладки з безхлорофільної паренхіми. У більших пучках крім обкладок спостерігаються тяжі коленхіми, які ніби з'єднують обидва боки листка. Коленхіма спостерігається також і по краях листкової пластинки, але, на відміну від попереднього виду, вона менше розвинена. В епідермальній тканині та безхлорофільній паренхімі містяться включення.

Стебло. На поперечному зрізі стебло практично округлої форми. Епідермальна тканина складена дрібними, прямокутної форми клітинами, в яких усі стінки потовщені. Епідерма однорядна, але, як і у попереднього виду, іноді спостерігається ще один внутрішній шар клітин, що прилягають до епідерми. Опушення відсутнє. Дуже рідко спостерігаються продихи. Кутикула ледь помітна (рис. 3).

На поперечному зрізі стебла чітко виділяється корова паренхіма, провідна система та серцевина.

Корова паренхіма представлена хлоренхімою, безхлорофільною паренхімою та луб'яними волокнами. На відміну від попереднього виду, корові провідні пучки не спостерігаються. Хлоренхіма представлена дрібними клітинами, приблизно такого ж розміру, як і клітини епідерми, які розміщені нещільно та орієнтовані горизонтально. Кількість їі клітинних шарів варіює від двох над пучками луб'яних волокон, до чотирьох - п’яти між ними. Безхлорофільна паренхіма слабше розвинена, ніж у попереднього виду, та представлена чотирма - п’ятьма шарами, що містяться у проміжках між луб'яними волокнами. Останні пучками розміщуються над флоемою провідних пучків і межують 3 одного боку $з$ епідермою, а $з$ іншого 3 шаром клітин безхлорофільної паренхіми. Луб’яні волокна в цього виду краще розвинені, ніж у попереднього.

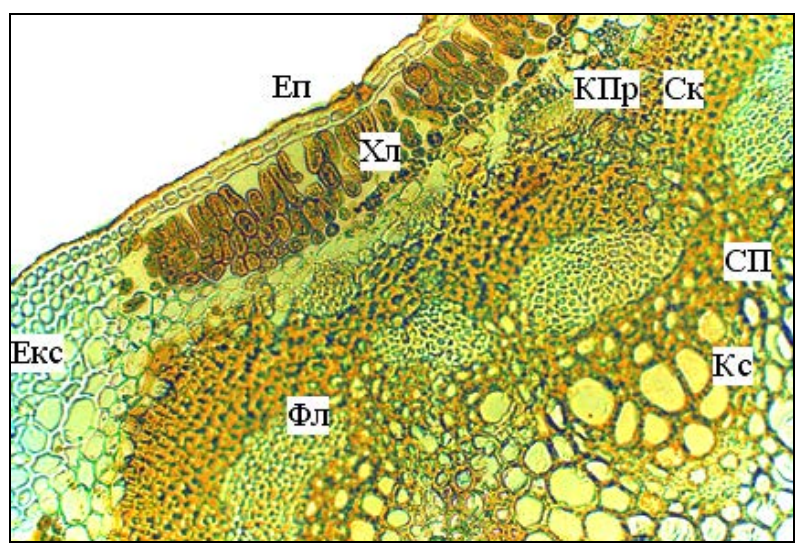

Рис. 3. Анатомічна будова стебла T. ucrainicus ( $\left.{ }^{\mathrm{x}} 75\right)$ : Кс - ксилема, Фл - флоема, БХл - безхлорофільна паренхіма, Хл - хлоренхіма, Еп - епідерма, Екс - екстраксилярні волокна, КПР - коровий провідний пучок, Ск - склеренхіма, СП - серцевинні (медулярні) промені

Провідна система, як і у T. borysthenicus, пучкового типу та слабко розвинена. Провідні пучки невеликі, більш-менш однакового розміру. Судини ксилеми середнього розміру, розміщуються в три - чотири ряди по чотири - п'ять найбільших судин у кожному. Невеликі «пучки» флоеми містяться над ксилемою. Провідні пучки один від одного відмежовані п'яти - шести рядними серцевинними променями, клітини яких досить сильно склерифіковані. 
Клітини серцевини тонкостінні та варіюють за розміром. У центральній частині клітини зруйнувались і утворилась порожнина. Перимедулярна зона чітко виражена, й у цій частині серцевини спостерігається багато молочників із включеннями.

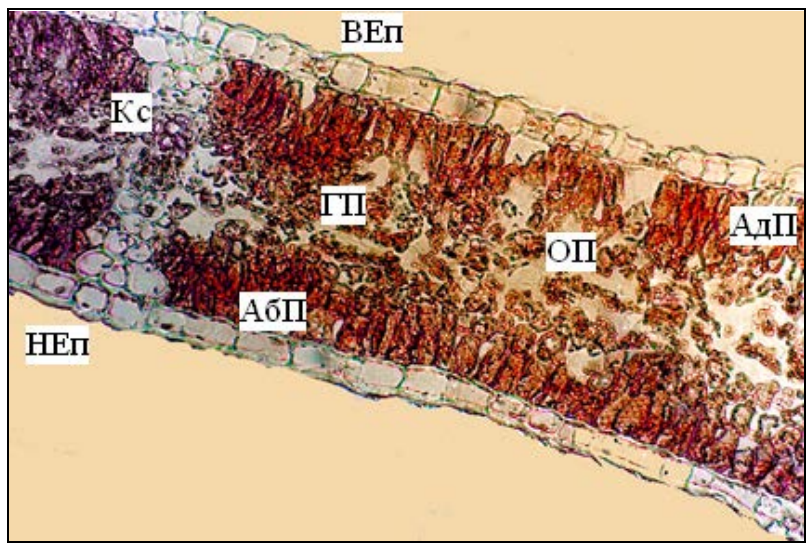

Рис. 4. Анатомічна будова листка T. borysthenicus ( $\left.{ }^{\mathrm{x}} 100\right)$ :

АдП - адаксіальна палісадна паренхіма, АбП - абаксіальна палісадна паренхіма, ГП - губчаста паренхіма, НЕп - нижня епідерма, ВЕп - верхня епідерма, ОП - обкладки провідних пучків, Кс - ксилема

T. orienthalis L. Листок. На поперечному зрізі листкова пластинка V-подібної форми. Товщина листкової пластинки дорівнює 291,8 \pm 4,1 мкм, і листок характеризується як товстий. На відміну від попередніх видів, ледь помітний шар кутикули спостерігали лише 3 верхнього боку листка в області середньої жилки (рис. 5б).

У парадермальній площині клітини верхньої та нижньої епідерм мають розпластані обриси та звивисті проекції над мезофілом і прямі обриси та прямокутні проекції над середньою жилкою та найбільшими бічними жилками. Як і у попередніх видів, продихи аномоцитного типу, розміщені більшменш рівномірно на обох епідермах, на одному рівні з іншими епідермальними клітинами. Однак, на відміну від попередніх видів, продихи орієнтовані своєю більшою віссю уздовж середньої жилки.

Покривна тканина представлена дрібноклітинною епідермою. Клітини верхньої епідерми на поперечному зрізі округлопрямокутної форми. Їх зовнішні стінки удвічі - втричі рази товщі, ніж інші клітинні стінки. Клітини нижньої епідерми також мають потовщені зовнішні стінки та розміром і формою не відрізняються від клітин верхньої епідерми. Загальна товщина епідермальної тканини дорівнює $15,5 \pm 0,9$ мкм, що становить 5\% товщини листкової пластинки. Верхня епідерма дещо товща порівняно 3 нижньою. Ї̈і товщина дорівнює $8,2 \pm$ 7,4 мкм, а нижньої - 7,4 $\pm 0,4$ мкм (табл. 1).

Мезофіл, на відміну від попереднього виду, дорзовентрально-ізолатеральний, його товщина дорівнює $253,1 \pm 5,3$ мкм, а за кількістю клітинних шарів - 10 (11) - характеризується як дуже багатошаровий. Адаксіальна палісадна паренхіма представлена двома шарами клітин циліндричної форми, які розміщені більш-менш щільно. Абаксіальна палісадна паренхіма складена двома (іноді трьома) шарами клітин, які розміщені дуже пухко, що не властиво палісадній тканині, одна з особливостей якої - компактне розміщення ії клітин, тому правильніше буде назвати цю тканину як несправжня палісадна. Губчаста тканина представлена п'ятьма - шістьма шарами клітин округлої форми. Оскільки клітини абаксіальної палісадної та губчастої тканин розміщені пухко, перехід від однієї до іншої тканини нечіткий.

Провідна система представлена центральним провідним пучком і бічними провідними пучками, які варіюють за розміром від великих до дрібних. В області центрального провідного пучка, як і в козельців дніпровських і на відміну від козельців українських, 3 адаксіального боку спостерігається масив клітин безхлорофільної паренхіми, який тягнеться з обох боків до сусідніх бічних пучків. Клітини безхлорофільної паренхіми тонкостінні та у п'ять - шість разів більші, ніж клітини епідерми. У центральному провідному пучку нараховують 11-13 середнього розміру судин ксилеми, розміщених у три ряди по три - чотири судини в кожному. Оточений пучок шаром клітин безхлорофільної паренхіми. Як і у попередніх видів, у даного $з$ абаксіального боку листка міститься тяж коленхіми, яка межує $з$ епідермою та провідними елементами пучка. Бічні провідні пучки, як і у попередніх видів, варіюють за розміром. На поперечному зрізі спостерігаються дві пари великих провідних пучків та 10-11 пар дуже дрібних, ледь помітних.

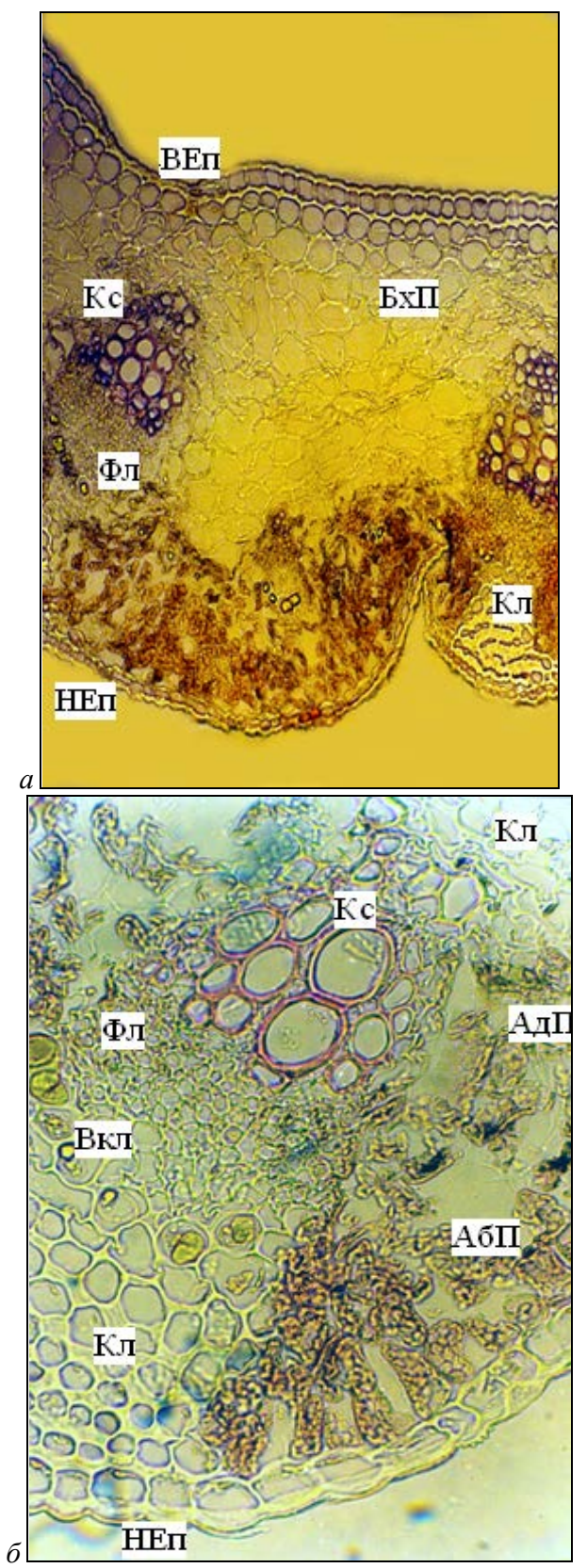

Рис. 5. Анатомічна будова середньої жилки листка T. borysthenicus $\left({ }^{\mathrm{x}} 100, a\right)$, T. orienthalis $\left({ }^{\mathrm{x}} 200, \sigma\right)$ : АдП - адаксіальна палісадна паренхіма, АбП - абаксіальна палісадна паренхіма, ГП - губчаста паренхіма, НЕп - нижня епідерма, ВЕп - верхня епідерма, Кс - ксилема, Фл - флоема,

Кл - коленхіма, БХл - безхлорофільна паренхіма,

Вкл - включення

У пучках більшого розміру чітко виражені обкладки 3 безхлорофільної паренхіми. Крім того, як і у попередніх видів, спостерігаються коленхімні «місточки», які ніби з'єднують 
протилежні боки листка. Пучки коленхіми містяться, як і у попередніх видів, по краях листкової пластинки. Але в цього виду пучки коленхіми приблизно такі, як у T. borysthenicus, та більшого розміру, ніж у T. ucrainicus. Включення спостерігаються у клітинах безхлорофільної паренхіми.

Стебло. На поперечному зрізі форма стебла майже округла. Епідермальна тканина представлена дрібними прямокутної форми клітинами 3 потовщеними зовнішніми стінками. Іноді зустрічаються продихи. На поперечному зрізі, як і у попередніх видів, чітко виділяється корова паренхіма, провідна система та серцевина (рис. 2). Корова паренхіма складається 3 хлоренхіми, безхлорофільної паренхіми, містить луб'яні волокна та корові провідні пучки. Клітини хлорофілоносної паренхіми мають округлу форму, на відміну від попередніх видів, розміщені пухко в два - три шари та орієнтовані горизонтально. Хлоренхіму іноді переривають невеликі пучки коленхіми, які межують 3 одного боку з епідермою, а 3 іншого - 3 флоемою. Крім цього, у коровій паренхімі, як і у козельців дніпровських, не так часто, але зустрічаються повноцінні корові провідні пучки. Безхлорофільна паренхіма розвинена слабше, ніж у попередніх видів, і складена двома - трьома шарами невеликих клітин, які мають тонкі стінки.

Провідна система, як і у попередніх видів, пучкового типу. Проте вона значно слабше розвинена, на поперечному зрізі займає приблизно $1 / 8$ його площі. Провідні пучки невеликі, майже однакового розміру. Судини ксилеми розміщені у два ряди по три - чотири судини в кожному. Невеликі «шапки» флоеми містяться над ксилемою. Пучки склеренхіми містяться по обидва боки від судин ксилеми, практично зливаються між собою та доходять до безхлорофільної паренхіми, розмежовуючи пучки флоеми. Отже, міжпучкові зони у цього виду виповнені склеренхімою, розміщеною в 13-15 рядів. У нього, на відміну від попередніх, слабше розвинена коленхіма, але досить сильно - склеренхіма.

Серцевина добре розвинена, займає приблизно половину поперечного зрізу стебла, складена тонкостінними клітинами однакового розміру. Перимедулярна зона виражена не чітко. Молочники у цього виду розміщені не лише в перимедулярній зоні, а й по всій серцевині.

\section{Обговорення}

В усіх досліджених видів на поперечному розрізі листкова пластинка $\mathrm{V}$-подібної форми із загнутими угору краями. Ступінь розвитку кутикули варіює: від добре вираженої (T. borysthenicus) до ледь помітної, в області середньої жилки (T. orienthalis). Розглядаючи епідермальну тканину, бачимо, що з поверхні листка клітини обох епідерм мають розпластані обриси та звивисті проекції над мезофілом, і прямі обриси та прямокутні проекції - над середньою жилкою та найбільшими бічними жилками. В усіх видів продихи аномоцитного типу, розміщені вони більш-менш рівномірно на обох епідермах, на одному рівні з іншими епідермальними клітинами, можуть бути орієнтовані своєю більшою віссю уздовж середньої жилки (T. orienthalis), або ж неорієнтованими, як у двох інших видів.

У досліджених видів покривна тканина представлена дрібноклітинною епідермою. Форма клітин верхньої епідерми на поперечному розрізі варіює від прямокутної (T. borysthenicus) до округло-прямокутної (T. orienthalis). Їх зовнішні стінки удвічі - втричі рази товщі, ніж інші клітинні стінки. У досліджених видів верхня епідермальна тканина краще розвинена порівняно $з$ нижньою.

У вивчених видів роду Tragopogon мезофіл ізолатерального типу (табл. 2). У T. orienthalis абаксіальна палісадна паренхіма розміщена досить пухко, що не характерно для цієї тканини, тому ми виділили цей тип мезофілу як несправжньо-ізолатеральний. В усіх досліджених видів, як правило, адаксіальна та абаксіальна паренхіми представлені двома шарами клітин. Не однакова щільність розміщення клітин нижньої палісадної паренхіми: найщільніше вона розміщена у T. borysthenicus, дуже пухко у T. orienthalis. Кількість шарів губчастої тканини варіює від двох у T. ucrainicus до п'яти - шести у T. orienthalis. Клітини, що складають цю тканину, округлої форми.

Таблиця 2

Якісні анатомічні ознаки представників роду Tragopogon

\begin{tabular}{|c|c|c|c|}
\hline Ознаки & $\begin{array}{l}\text { T. borysthenicus, } \\
\text { ЧДБЗ, Івано- } \\
\text { Рибальчанська } \\
\text { ділянка }\end{array}$ & $\begin{array}{l}\text { T. ucrainicus, } \\
\text { м. Київ, лівий } \\
\text { берег р. Дніпро }\end{array}$ & $\begin{array}{l}\text { T. orienthalis, } \\
\text { Чернігівська } \\
\text { обл., с. Красне }\end{array}$ \\
\hline \multicolumn{4}{|c|}{ Листок } \\
\hline \multicolumn{4}{|c|}{$\begin{array}{c}\text { Мезофіл } \\
\text { Палісадна тканина (кількість шарів) }\end{array}$} \\
\hline Адаксіальної & 2 & 2 & 2 \\
\hline Абаксіальної & 2 & 2 & 2 (рідко 3) \\
\hline $\begin{array}{l}\text { Губчаста тканина } \\
\text { (кількість шарів) }\end{array}$ & 3 & 2 (рідко 3) & $5-6$ \\
\hline Тип & і/л & $\mathrm{i} /$ л & н/л \\
\hline Кількість шарів мезофілу & $\begin{array}{l}7 \\
\text { Ксилема }\end{array}$ & 6 (рідко 7) & 10 (рідко 11) \\
\hline $\begin{array}{l}\text { кількість судин у цен- } \\
\text { тральному провідному пучку }\end{array}$ & 12-14 & $6-7$ & $11-13$ \\
\hline \multicolumn{4}{|c|}{ Стебло } \\
\hline $\begin{array}{l}\text { Кількість шарів } \\
\text { хлоренхіми }\end{array}$ & $4-5$ & $\begin{array}{c}2 \\
\text { (4 у проміжках) }\end{array}$ & $2-3$ \\
\hline $\begin{array}{l}\text { Кількість шарів безхло- } \\
\text { рофільної паренхіми }\end{array}$ & $6-8$ & $4-5$ & $2-3$ \\
\hline $\begin{array}{l}\text { Кількість судин у } \\
\text { провідних пучках }\end{array}$ & 14-15 & $15-16$ & $6-8$ \\
\hline Корові провідні пучки & наявні & відсутні & наявні \\
\hline Молочники & перимедуля & ярна зона & по всій серцевині \\
\hline
\end{tabular}

Як і у представників інших родів родини Asteraceae (Metcalfe and Chalk, 1950), у видів цього роду провідна система представлена центральним провідним пучком і бічними провідними пучками, які варіюють за розміром від великих до дрібних. Як правило, спостерігаються дві пари великих провідних пучків та 9-11 пар дуже дрібних, ледь помітних. В області центрального провідного пучка з адаксіального боку спостерігається масив клітин безхлорофільної паренхіми, який тягнеться з обох боків до сусідніх бічних пучків (у козельців дніпровських та східних), на відміну від козельців українських, у яких основна паренхіма з нижнього боку листка значно менше розвинена. Клітини безхлорофільної паренхіми тонкостінні та приблизно у п'ять - шість разів більші, ніж клітини епідерми. У центральному провідному пучку нараховується від шести восьми (T. ucrainicus) до 14-16 (T. borysthenicus та T. ucrainicus) судин ксилеми середнього розміру. В усіх видів 3 абаксіального боку листка міститься тяж коленхіми, що межує 3 епідермою та провідними елементами пучка. Наявність обкладок із безхлорофільної паренхіми варіює: у T. borysthenicus yсі провідні пучки їх мають, а у T. orienthalis спостерігаються лише у великих. В усіх досліджених видів в області великих провідних пучків спостерігаються коленхімні балки, що з'єднують обидва боки листка. Крім цього, характерна наявність пучків коленхіми по краях листкової пластинки. Включення спостерігаються у клітинах епідерми, мезофілу, безхлорофільної паренхіми. Таким чином, для анатомічної будови листків досліджуваних козельців характерні: порівняно великі та товстостінні клітини епідерми, варіювання типів та кількості шарів мезофілу, варіювання ступеня розвитку безхлорофільної паренхіми, тяжі коленхіми з обох боків провідних пучків (табл. 2).

В усіх досліджених видів форма стебла на поперечному зрізі майже округла. Епідермальна тканина дрібноклітинна, клітини прямокутної форми 3 потовщеними зовнішніми стінками. Дуже рідко зустрічаються продихи. Чітко виділяється корова паренхіма, провідна система та серцевина. Корова паренхіма складається 3 хлоренхіми, безхлорофільної паренхіми, містить луб'яні волокна та корові провідні пучки (T. orienthalis i T. borysthenicus). Клітини хлорофілоносної паренхіми варіюють за формою від овальних (T. borysthenicus) до округ- 
лих (T. orienthalis), кількість шарів клітин також не постійна, варіює від двох - трьох до п'яти. В усіх досліджених видів хлоренхіму іноді переривають пучки коленхіми. У коровій паренхімі у козельців дніпровських і козельців східних зустрічаються повноцінні корові провідні пучки.

У видів роду Tragopogon провідна система пучкового типу. Провідні пучки варіюють за розміром від середніх (T. borysthenicus) до дрібних (T. orienthalis). Медулярні промені в усіх козельців дуже широкі. Найменш склерофіковані вони у козельців дніпровських, дещо сильніше у козельців українських і повністю - у козельців східних. В останніх пучки склеренхіми містяться по обидва боки від судин ксилеми, практично зливаються між собою та доходять до безхлорофільної паренхіми, розмежовуючи пучки флоеми.

У представників роду Tragopogon серцевина добре розвинена. Складена вона тонкостінними клітинами однакового розміру. Перимедулярна зона виражена не чітко. Молочники спостерігаються в перимедулярній зоні, в центрі серцевини.

Отже, для анатомічної будови стебла видів роду Tragopogon характерний чіткий поділ на корову частину, провідну систему та серцевину, товстостінні клітини епідерми, варіювання розвитку безхлорофільної паренхіми та хлоренхіми, відсутність або наявність корових провідних пучків, пучковий тип провідної системи, тонкостінні клітини серцевини та наявність у ній молочників.

У результаті порівняльного аналізу анатомічної будови листків і стебел представників роду Tragopogon виявлені ознаки, спільні для цих видів. До таких ознак належать амфістоматичний тип будови листка, аномоцитні незанурені продихи, диференціація тканин у стеблі на корову паренхіму, провідну систему та серцевину, пучковий тип провідної системи. Ці ознаки, на нашу думку, можна розглядати як додаткові діагностичні на рівні родини, бо вони характерні як і для раніше досліджуваних нами родів, так і для інших представників родини Asteraceae (Metcalf and Chalk, 1950; Ninova 1976a; 1976b; Fahn, 1988; Badanina et al., 1994; Badanina and Brajon, 1996; Futorna, 2001; 2006; Qureshi et al., 2008; Futorna et al., 2016).

Спостерігаються ознаки, спільні для досліджених видів, але які відрізняють їх від інших представників цієї родини. До таких ознак, зокрема, належить наявність молочників (Fahn, 1988; Novak et al., 1991; Soltis et al., 1995).

За результатами аналізу анатомічної будови виявлено ознаки, які відрізняють досліджені види роду Tragopogon один від одного. Як видно 3 таблиці 2, досліджені види характеризуються наявністю чи відсутністю корових провідних пучків та присутністю молочників у серцевині. У T. borysthenicus та T. orienthalis спостерігаються корові провідні пучки, а у T. исrainicus вони відсутні. Молочники у T. borysthenicus i T. ucrainicus містяться у перимедулярній зоні, а у T. orienthalis - по всій серцевині. Отже, $T$. borysthenicus характеризується наявністю корових провідних пучків і розміщенням молочників у перимедулярній зоні серцевини; у T. ucrainicus молочники також містяться у перимедулярній зоні, але корові пучки відсутні; у T. orienthalis спостерігаються корові провідні пучки, але молочники містяться по всій серцевині. На нашу думку, ці ознаки можуть бути додатковими діагностичними для досліджених видів.

Таблиця 3

Порівняльно-анатомічна характекристика видів роду Tragopogon

\begin{tabular}{|c|c|c|c|c|c|c|}
\hline Види & $\begin{array}{c}\text { Тов- } \\
\text { щина } \\
\text { листка }\end{array}$ & $\begin{array}{l}\text { Мезофіл: } \\
\text { тип, } \\
\text { кількість } \\
\text { шарів }\end{array}$ & $\begin{array}{c}\text { Палісадна } \\
\text { тканина, } \\
\text { кількість } \\
\text { шарів }\end{array}$ & $\begin{array}{c}\text { Адаксіальна } \\
\text { епідерма, } \\
\text { товщина, } \\
\text { мкм } \\
\end{array}$ & $\begin{array}{c}\text { Опу- } \\
\text { шення }\end{array}$ & $\begin{array}{c}\text { Об- } \\
\text { кладки }\end{array}$ \\
\hline T. orienthalis & товста & д/110 (11) & $2 / 2$ & 8,17 & - & - \\
\hline T. ucrainicus & середня & і/л 6 (7) & $2 / 2$ & 8,43 & - & + \\
\hline T. borysthenicus & товста & і/л 7 & $2 / 2$ & 10,08 & - & + \\
\hline
\end{tabular}

Примітка: д/i - дорзовентральний мезофіл, i/л - ізолатеральний мезофіл.
У результаті дослідження трьох видів роду ми виявили ознаки, що відрізняють види, але не можуть використовуватись 3 метою систематики. Вивчені види відрізняються товщиною листкової пластинки. Найтонша пластинка спостерігається у T. исrainicus, а найтовща у T. orienthalis (табл. 3). В останнього виду спостерігається найбільша шаруватість мезофілу (дуже багатошаровий). Тип мезофілу також варіює від ізолатерального (T. borysthenicus i T. ucrainicus) до несправжньо-ізолатерального (T. orienthalis). Кількість шарів палісадної паренхіми (як адаксіальної, так i абаксіальної) практично не змінюється у видів, лише у T. orienthalis рідко спостерігається третій шар клітин. Відрізняються види ступенем розвитку губчастої паренхіми. Найкраще вона розвинена у $T$. orienthalis (п'ять - шість шарів клітин) і найгірше у $T$. borysthenicus (два шари клітин). Відмінності між видами спостерігаються в анатомічній будові стебла. Найкраще розвиненою хлоренхімою характеризується $T$. borysthenicus (чотири - п’ять шарів) і найменш розвиненою - T. orienthalis (два - три шари клітин) (табл. 3). Безхлорофільна паренхіма, одна із функцій якої - запасання води, найбільшою кількістю шарів представлена у T. borysthenicus, дещо меншою - у T. ucrainicus, найменш розвинена вона у T. orienthalis (табл. 3). У трьох досліджених видів провідна система розвинена приблизно однаковою мірою. У T. borysthenicus спостерігається більша кількість судин ксилеми в листку та стеблі, але вони значно меншого розміру порівняно 3 двома іншими видами. У результаті аналізу можна зробити висновок, що в усіх досліджених видів роду Tragopogon в анатомічній будові спостерігається поєднання ксероморфних і мезоморфних ознак. Найбільш ксероморфною структурою характеризується $T$. borysthenicus iз Чорноморського заповідника, і найменшою - T. orienthalis із піщаних терас р. Десна (Чернігівська обл.).

Butnik et al. (1991), досліджуючи рослини Середньої Азії, зробили висновок, що рослини екстремальних умов зростання, до яких досить часто відносять екологічну групу псамофітів, мають часто високоспеціалізовану будову в поєднанні з елементами сукулентності. Nikolajevska (1968), досліджуючи злаки - псамофіти нижньодніпровських пісків, установила, що вони мають менш ксероморфну будову порівняно з близькими до них ксерофітами. Наші дослідження показали, що в анатомічній будові псамофітів із роду Tragopogon флори України спостерігається поєднання ознак мезофітів і ксерофітів.

\section{Висновки}

Анатомічна будова асимілювальних органів псамофітних видів роду Tragopogon характеризується поєднанням ксероморфних і мезоморфних ознак. Спільними ксероморфними ознаками для досліджених видів виступають: амфістоматичний тип листка, згортання листкової пластинки, наявність трихом (однак їх будова та тип опушення різні в різних видів) або потужної кутикули у поєднанні з товстостінними епідермальними клітинами, наявність безхлорофільної паренхіми та включень.

Ознаки мезоморфності - не занурені продихи, слабкий розвиток провідної системи та механічних елементів, крупноклітинність тканин стебла та листка. Для кожного з досліджених видів комплекс таких ознак адаптивний, виник під час індивідуального розвитку рослин за певних умов навколишнього середовища. Чим менш аридними стають умови, тим більш мезоморфною виявляються структура листка та стебла видів роду Tragopogon. Ступінь мезоморфності, за нашими даними, збільшується в напрямку 3 півдня на північ. Найбільш ксероморфною структурою характеризується $T$. borysthenicus iз Чорноморського заповідника, найменшою - T. orienthalis із піщаних терас р. Десна (Чернігівська обл.).

Ми виділили комплекс анатомічних ознак, які можуть бути додатковими діагностичними для досліджених видів; T. borysthenicus характеризується наявністю корових провідних пучків і розміщенням молочників у перимедулярній зоні серцевини; у T. исrainicus молочники також містяться в перимедулярній зоні, але корові пучки відсутні; у T. orienthalis спостерігаються корові провідні пучки, але молочники містяться по всій серцевині. 


\section{References}

Badanina, V. A., \& Brajon, O. V. (1996). Sekretomi kanaly u vydiv rodu Doronicum L. (Asteraceae) [Secretory channels of the genus Doronicum L. species (Asteraceae)]. Ukrainian Botanical Journal, 53(1-2), 48-51 (in Ukrainian).

Badanina, V. A., Brajon, O. V., \& Chopyk, V. I. (1994). Porivnjal'na morfologoanatomichna harakterystyka stebla vydiv rodu Doronicum L. (Asteraceae) flory Ukrajiny [Comparative morphological and anatomical characteristics of the stem of species of the genus Doronicum L. (Asteraceae) of the flora of Ukraine]. Ukrainian Botanical Journal, 51(5), 40-47 (in Ukrainian).

Borisova, A. G. (1964). Rod Tragopogon - Kozloborodnik. Flora SSSR [Flora of the USSR]. Vol. 29. Izdatel'stvo AN SSSR, Moscow-Leningrad (in Russian)

Butnik, A. A., \& Saidov, D. K. (1971). Strukturnye osobennosti form izenja v ontogeneze [Structural features of forms of Kochia in ontogenesis]. In: Izen' Kochia prostrota (L.) Schrad. FAN, Tashkent. pp. 68-94 (in Russian).

Butnik, A. A., \& Tymchenko, O. V. (1987). Stroenie jepidermy list'ev vidov semejstva Chenopodiaceae Vent. [Structure of the epidermis of leaves of the Chenopodiaceae Vent. family]. Botanical Joumal, 72(8), 1021-1030 (in Russian).

Butnik, A. A., Nigmanova, R. N., Pajzieva, S. A., \& Saidov, D. K. (1991). Ekologicheskaja anatomija pustynnyh rastenij Srednej Azii [Ecological anatomy of desert plants of Central Asia]. Izdatel'stvo FAN Uzbekskoj SSR, Tashkent (in Russian).

Bykov, B. A., \& Stepanova, E. F. (1953). Kustarnikovye stepi kak tip rastitel’nosti [Shrubby steppes as a type of vegetation]. Proceedings of the All-Union Geographical Society, 1, 85 (in Russian).

Caroliin, R. C., Jacobs, S. W., \& Vesk, M. (1978). Kranz cells and mesophyll in the Chenopodiaceae. Australian Journal of Botany, 26, 683-698.

Fahn, A. (1988). Secretory tissues in vascular plants. New Phytologist, 108, 229 257.

Furst, G. G. (1979). Metody anatomo-gistohimicheskogo issledovanija rastitel'nyh tkanej [Methods of anatomo-histochemical study of plant tissues]. Nauka, Moscow (in Russian).

Futorna, O. A. (2001). Anatomichna budova vegetatyvnyh organiv Helichrysum arenarium ta $H$. corymbiforme (Asteraceae Dumort.) [Anatomical structure of the vegetative organs Helichrysum arenarium and $H$. corymbiforme (Asteraceae Dumort.). Ukrainian Botanical Journal, 1, 111-120 (in Ukrainian).

Futorna, O. A. (2006). Anatomichna harakterystyka Jurinea laxa Fish. ex Iljin. [Anatomical characteristic of Jurinea laxa Fish. ex Iljin.]. Scientific Bulletin of Chemivtsi University, 298, 259-268 (in Ukrainian).

Futoma, O. A., Zhygalova, S. L., \& Ol'shans'kyj, I. G. (2016). Mikromorfologichna harakterystyka (anatomichna struktura lystkiv ta stebel, ul'trastruktura plodiv, ul'traskul'ptura pylkovyh zeren) Sonchus oleraceus L. (Asteraceae) [Micromorphological characteristic (anatomical structure of leaves and stems, fruit ultrastructure, ultrasculpturus of pollen grains) of Sonchus oleraceus L. (Asteraceae)]. Chomomorski Botanical Joumal, 12(2), 141-153 (in Ukrainian).

Grigore, M.-N., \& Toma, C. (2010). Halofitele. Aspecte de anatomie ecologică. Edit. Univ. Al. I. Cuza, Iaşi.

Kamilova, F. N. (1954). K anatomicheskoj harakteristike list'ev i pobegov nekotoryh vidov grebenshhika [To the anatomical characteristics of leaves and shoots of some species of the comber]. Reports of the Academy of Sciences of the Uzbek SSR, 7, 61-67 (in Russian).

Klokov, M. V. (1946). Tragopogon L. In: Flora URSR. AN URSR, Kyiv. Vol. 12. pp. 217-246, 561-567 (in Ukrainian).

Metcalfe, C. R., \& Chalk, L. (1950). Anatomy of the Dicotyledons leaves stem and wood in relation to taxonomy with notes on economic uses. Vol. 2. Claredon Press, Oxford.

Nikitin, S. A. (1966). Drevesno-kustarnikovaja rastitel'nost' SSSR [Tree and shrub vegetation of the USSR]. Nauka, Moscow (in Russian).
Nikolajevs'ka, L. D. (1968). Osoblyvosti anatomichnoi' budovy dejakyh zlakivpsamofitiv Nyzhn'odniprovs'kyh piskiv [Features of anatomical structure of some cereals-psamophytes of Nizhnedniprovsky sands]. Ukrainian Botanical Journal, 25(2), 61-69 (in Ukrainian).

Ninova, D. (1976a). Ekologo-anatomicheskie, anatomo-taksonomicheskie i anatomo-filogeneticheskie zametki o sekcijah roda Centaurea L. I. Sekcija Centarium DC. [Ecological-anatomical, anatomical-taxonomic and anatomicalphylogenetic notes on sections of the genus Centaurea L. I. Section Centarium DC.]. Scientific works of the Plovdiv University of Biology, 14(4), 91104 (in Russian).

Ninova, D. (1976b). Ekologo-anatomicheskie, anatomo-taksonomicheskie i anatomo-filogeneticheskie zametki o sekcijah roda Centaurea L. I. Sekcija Cyanus DC. [Ecological-anatomical, anatomical-taxonomic and anatomical-phylogenetic notes on sections of the genus Centaurea L. I. Section Cyanus DC.] Scientific works of the Plovdiv University of Biology, 14(4), 105-123 (in Russian).

Novak, S. J., Soltis, D. E., \& Soltis, P. S. (1991). Onwbey’s Tragopogons 40 years later. American Joumal of Botany, 78(11), 1586-1600.

Öznur, E. A. (2007). Morphological and anatomical characteristics of Cichorium intybus L., Tragopogon latifolius Boiss. and Tussilago farfara L. (Asteraceae). International Journal of Natural and Engineering Sciences, 1(3), 81-85.

Qureshi, S. J., Khan, M. A., \& Ahmad, M. (2008). Comparative morphology, palynology and anatomy of five astraceous species from Pakistan. African Journal of Agricultural Research, 3(9), 622-632.

Qureshi, S. J., Khan, M. A., \& Subhan, K. (2008). Comparative morphology, palynology and anatomy of two asteraceae species. Trakia Journal of Sciences, 6(4), 52-61.

Shijrevdamba, C. (1989). Anatomicheskaja harakteristika rastenij osnovnyh prirodnyh zon i pojasov Mongol'skoj Narodnoj Respubliki [Anatomical characteristics of plants in the main natural zones and belts of the Mongolian People's Republic]. BIN, Leningrad (in Russian).

Shijrevdamba, C., \& Gamalej, J. V. (1990). Sravnitel'naja anatomija rastenij jekologo-geograficheskih zon Mongolii [Comparative anatomy of plants in Mongolia's ecological and geographical zones]. Materials of the II All-Union Conference "Modern Problems of Ecological Anatomy of Plants". Izdatel'stvo Dal'nevostochnogo Universiteta, Vladivostok, 178-180 (in Russian).

Shmal'gauzen, I. I. (1897). Flora Srednej i Juzhnoj Rossii, Kryma i Sevemogo Kavkaza. T. 2: Dvudol'nye srostnolepestnye i bezlepestnye, odnodol'nye, golosemennye i vysshie sporovye: Rukovodstvo dlja opredelenija semennyh i vysshih sporovyh rastenij [Flora of Central and Southern Russia, Crimea and the North Caucasus. Vol. 2: Dicotyledonous and non-flocking, monocotyledons, gymnosperms and higher spore: Guidelines for the determination of seed and higher spore plants]. Tipografija tovarishestva pechatnogo dela i torgovli I. N. Kushnereva i K ${ }^{\circ}$ v Moskve, Kievskoe otdelenie, Kiev (in Russian).

Solereder, H. (1899). Systematische Anatomie der Dicotyledonen. Fr. Enke Verlag, Stuttgart.

Soltis, P. S., Plunkett, G. M., Novak, S. J., \& Soltis, D. E. (1995). Genetic variation in Tragopogon species: Additional origins of the allotetraploides T. marus and T. miscellus (Composite). American Journal of Botany, 82(10), $1329-1341$.

Stocker, O. (1928). Das Halophytenproblem. Ergebnisse der Biologie, 3, 169.

Tsvelev, N. N. (1989). Tragopogon. In: Flora Evropeyskoy chasty SSSR [Flora of the European part of the USSR]. Leningrad, Nauka. Vol. 8, 46-56 (in Russian).

Vasil'ev, B. R. (1988). Stroenie lista drevesnyh rastenij razlichnyh klimaticheskih zon [The structure of a leaf of woody plants of different climatic zones] LGU, Leningrad (in Russian).

Zaharevich, S. F. (1954). K metodike opisanija jepidermisa lista [To the technique of describing the leaf epidermis]. Vestnik of Pushkin Leningrad State University, 4, 65-75 (in Russian). 